\title{
MINAT MASYARAKAT TERHADAP MODEL PENDIDIKAN MADRASAH DI MAGELANG DAN DEMAK
}

\author{
Oleh: Aji Sofanudin \\ Peneliti pada Balai Penelitian dan Pengembangan Agama Semarang \\ Jl Untung Suropati Kav. 70 Ngaliyan Semarang \\ email: ajirakhma@yahoo.com
}

\begin{abstract}
This study aims to determine how the model of the enlargement of public interest in Islamic school (madrasah) is. This study used the Research and Development method. Sources of data were parents of students and administrators of Islamic Elementary School (MI) and Islamic Junior High School (MTs) in Central Java. The findings show that highly demanded madrasah model is madrasah which having a concern with the community assessment aspect and the madrasah management. The enlargement of public interest model in madrasah is done through the following efforts (1) Formation of Madrasah Positive Image, (2) Madrasah Achievement; Academic and Non-academic, (3) Intensification and Extensification of Madrasah Publication, (4) Featured Program oriented to the community needs, (5) Compliance with National Education Standard, (6) Attractive Appearance of Madrasah.
\end{abstract}

Keywords: Islamic School (Madrasah) Model, Interests, Community

\begin{abstract}
Abstrak
Penelitian ini bertujuan untuk mengetahui bagaimana model peningkatan minat masyarakat terhadap madrasah. Penelitian ini menggunakan Research and Development. Sumber datanya adalah orang tua siswa dan pengelola Madrasah Ibtidaiyah dan Tsanawiyah di Jawa Tengah. Hasilnya, model madrasah yang diminati masyarakat adalah madrasah yang memperhatikan aspek penilaian masyarakat dan pengelolaan madrasah. Model peningkatan minat masyarakat terhadap madrasah melalui upaya sebagai berikut (1) Pembentukan Citra Positif Madrasah, (2) Peningkatan Prestasi Madrasah; Akademik dan Non akademik, (3) Intensifikasi dan ekstensifikasi Publikasi Madrasah, (4) Program Unggulan yang Berorientasi Kebutuhan Masyarakat, (5) Pemenuhan Standar Nasional Pendidikan, (6) Penampilan Madrasah yang Menarik.
\end{abstract}

Kata Kunci: Model Madrasah, Minat, Masyarakat

\section{PENDAHULUAN}

\section{Latar Belakang Masalah}

Sejak Undang-undang Nomor 20 Tahun 2003 Tentang Sistem Pendidikan Nasional, madrasah menempati posisi yang sejajar dengan sekolah umum sesuai dengan tingkatannya. Meskipun disadari bahwa secara kualitas belum tentu sama. Pencitraan ma- drasah sebagai lembaga pendidikan "kelas dua", sebenarnya tidak lagi menemukan justifikasinya sejak diterapkannya undangundang ini.

Meskipun dari sisi legal-formal posisinya sama namun minat masyarakat untuk menyekolahkan anak mereka ke madrasah disinyalir rendah. Hal ini terungkap dari hasil penelitian Achmad yang menunjukkan

Naskah diterima 7 September 2012. Revisi pertama 5 Oktober 2012, revisi kedua 4 November 2012, dan revisi terakhir 24 November 2012 
bahwa secara nasional terjadi penurunan Angka Partisipasi Kasar (APK) Madrasah Ibtidaiyah dari tahun 2003 ke 2006 padahal di lain pihak APK SD dan MI mengalami kenaikan. Ini mengindikasikan adanya penurunan minat orang tua untuk mempercayakan pendidikan anaknya ke madrasah. Kenaikan APK pada MTs selama periode tahun 2003-2006 justru mengindikasikan lain hal mengingat asal sekolah siswa baru yang mendaftar ke MTs mencapai lebih dari 70 persen berasal dari sekolah SDN dan SD swasta. Kondisi ini bisa jadi karena daya tampung SMPN maupun swasta terbatas, sehingga lulusan SD banyak yang melanjutkan sekolahnya ke Madrasah Tsanawiyah. ${ }^{1}$

Berdasarkan rasio jumlah murid dengan jumlah kelas dan sekolah di mana jumlah murid per kelas/persekolah dari madrasah umummnya lebih rendah dari total Nasional masing-masing menurut jenjang pendidikannya. Hal ini menunjukan masih rendahnya daya tampung madrasah. Minimnya siswa bisa ditingkatkan lagi dengan meningkatkan mutu pendidikan madrasah sehingga minat untuk bersekolah di madrasah makin besar pula.

Trend penurunan minat terhadap madrasah ini tidak terjadi pada semua madrasah. MIN, MTsN, dan MAN 3 di Malang dikenal sebagai madrasah unggul yang banyak diminati masyarakat. ${ }^{2} \mathrm{Di}$ Jawa Tengah ada beberapa MI dan MTs yang unggul yang menyeleksi dan menolak murid di antaranya MI Ma'arif Grabag 1, MIN Bawu, MIN Boyolali, MIN Jetis, MIN Banyumas, MIN Pekalongan, MI Banat, MIN Cepu, MI Sambas Purbalingga, MTs N Bawu, MTs Rambatan, MTs Winong, MTs N 1 Surakarta, MTs N 2 Surakarta, MTs N Parakan,

${ }^{1}$ Zainal Achmad. 2007. Analisis Tingkat Partisipasi Pendidikan Siswa Madrasah, www.pendis.kemenag.go.id, diakses 7 Mei 2012.

${ }^{2}$ Mulyani Mudis Taruna. 2009. Pelaksanaan KTSP pada Madrasah Tsanawiyah Negeri di Kalimantan Selatan, Jawa Timur, dan DIY. Semarang: Balai Penelitian dan Pengembangan Agama Semarang.
MTs N 1 Kebumen, MTs Banyumas, MTs N Brebes, MTs N Boyolali, MTs N 1 Susukan, serta MTs N 2 Susukan. ${ }^{3}$ Namun, secara umum ada penurunan minat masyarakat terhadap madrasah terutama pada madrasah-madrasah swasta.

Selain itu, madrasah juga mengidap persoalan utama yang pada umumnya kalah bersaing dengan sekolah umum untuk memperebutkan calon siswa berprestasi. Siswa berprestasi umumnya lebih memilih sekolah umum daripada madrasah karena mereka beranggapan bahwa sekolah umum lebih menjanjikan harapan bahwa prestasi mereka akan lebih baik di sana. Madrasah dianggap kalah mutu jika dibandingkan dengan sekolah umum. Siswa madrasah juga sering merasa rendah diri jika berhadapan dengan siswa sekolah umum yang setara dengan sekolahnya. $\mathrm{kan}^{4}$

Pengalaman Suprayogo, menyebut-

Sudah sekian lama saya mengikuti perbincangan tentang madrasah. Dalam perbincangan itu kesimpulan yang selalu dimunculkan adalah bahwa madrasah selalu tertinggal bilamana dibandingkan dengan sekolah umum. Prestasi hasil belajar para siswanya rendah, lembaga pendidikan Islam ini dikelola dengan manajemen seadanya, gurunya kurang berkualitas, dan gajinya pun rendah. Begitu pula sarana dan prasarana pendidikan tersedia apa adanya.

Penelitian dari Tim Peneliti STAIN Salatiga (2006) tentang "Fenomena Madrasah Bubar dan Islamic Full Day School" (Studi Atas Persepsi dan Aspirasi Masyarakat Muslim Kota Surakarta dan Sekitarnya terhadap MI dan SDIT) menunjukkan banyak

\footnotetext{
${ }^{3}$ Wawancara dengan Kasi Kurikulum Kanwil Kementerian Agama Propinsi Jawa Tengah, H Sofie, di Hotel Amanda, tanggal 5 Juli 2012.

${ }^{4}$ Imam Suprayogo. 2007. Quo Vadis Madrasah; Gagasan, Aksi, dan Solusi Pembangunan Madrasah, Jakarta: Puslitbang Pendidikan Agama dan Keagamaan, h. 6.
} 
MI yang mengalami penurunan bahkan bubar dan tergantikan oleh SDIT. ${ }^{5}$

Madrasah mengalami penurunan bahkan bubar dan tergeser oleh sekolah-sekolah baru disebabkan: 1) Kinerja guru rendah, kurang profesional; 2) Kepemimpinan Kepala MI; 3) Lokasi Madrasah kurang strategis, berdekatan dengan SD Inpres; 4) Adanya guru-guru yang bermasalah.

Data Kementerian Agama menyebutkan bahwa 91,5\% madrasah adalah swasta. Ini artinya partisipasi masyarakat terhadap madrasah sangat tinggi. Bahkan bisa dikatakan bahwa madrasah sesungguhnya adalah milik masyarakat bukan pemerintah. ${ }^{6}$

Berdasarkan uraian di atas, tulisan ini ingin mengungkap bagaimana minat masyarakat terhadap madrasah di kabupaten Magelang dan kabupaten Demak sebagai daerah sentra-madrasah di Jawa Tengah.

\section{Rumusan Masalah}

1. Bagaimanakah minat masyarakat terhadap madrasah di Magelang dan Demak?

2. Bagaimanakah model peningkatan minat masyarakat terhadap madrasah di Magelang dan Demak?

\section{Tujuan dan Manfaat Penelitian}

Penelitian ini bertujuan untuk mengungkap model madrasah yang diminati masyarakat. Penelitian ini bermanfaat sebagai bahan masukan untuk penyusunan kebijakan oleh pemerintah, cq Kementerian Agama RI terkait dengan model peningkatan minat masyarakat terhadap madrasah. Manfaat lain adalah dapat dijadikan rujukan bagi madrasah yang diteliti dan madra-

${ }^{5}$ http:/ / balitbangdiklat.kemenag.go.id/index. php?option $=$ com_content $\&$ view $=$ article $\&$ id $=286$ : fenomena-madrasah-bubar-dan-islamic- full-dayschool, diakses 21 Maret 2012.

${ }^{6}$ Majalah Rindang, Kanwil Kementerian Agama Propinsi Jawa Tengah, Edisi Maret 2012, hal. 29. sah pada umumnya untuk meningkatkan jumlah peserta didik di madrasah.

\section{TINJAUAN PUSTAKA}

Minat (interest) dapat dikatakan lawan dari keengganan (aversion) yang dirumuskan sebagai kecenderungan untuk menjauhi terjadinya pengalaman tentang objek-objek. Minat dan keengganan sifatnya dinamik. Pada satu saat mungkin minat lebih kuat daripada keengganan, disebabkan individu yang bersangkutan memusatkan perhatian kepada salah satu objek sehingga tidak ada kesempatan untuk memperhatikan objek lain.

Menurut Djamarah (2009) minat merupakan kecenderungan psikologis yang menyenangi sesuatu objek dan belum sampai melakukan kegiatan. Minat merupakan potensi psikologi yang dapat dimanfaatkan untuk menjadi motivasi. Kecenderungan yang menetap untuk memperhatikan dan mengundang beberapa aktivitas. Seseorang yang berminat terhadap suatu aktivitas akan memperhatikan aktivitas itu secara konsisten dalam rasa senang. Dengan kata lain, minat adalah suatu rasa lebih suka dan rasa ketertarikan pada suatu hal atau aktivitas tanpa ada yang menyuruh. Minat pada dasarnya adalah penerimaan akan suatu hubungan antara diri sendiri dengan sesuatu di luar diri. Semakin kuat atau dekat hubungan tersebut, semakin besar minat. (Djamarah 2009:132).

Suatu anggapan yang keliru adalah mengatakan bahwa minat dibawa sejak lahir. Minat adalah perasaan yang didapat karena berhubungan dengan sesuatu. Minat terhadap sesuatu itu dipelajari dan dapat mempengaruhi belajar selanjutnya serta mempengaruhi penerimaan minat baru. Jadi minat terhadap sesuatu merupakan hasil belajar dan cenderung mendukung aktivitas belajar berikutnya.

Minat ialah sesuatu pemusatan perhatian yang tidak disengaja yang terlahir dengan penuh kemauannya dan yang 
tergantung dari bakat dan lingkungannya (Sujanto 2008:92). Minat berarti kecenderungan dan kegairahan yang tinggi atau keinginan yang besar terhadap sesuatu (Syah, 2004: 136). Menurut Ruber (1988) minat tidak termasuk istilah populer dalam psikologi karena ketergantungannya yang banyak pada faktor-faktor internal lainnya seperti pemusatan perhatian, keingintahuan, motivasi, dan kebutuhan.

WS Winkel memberikan definisi minat adalah kecenderungan yang agak menetap dalam subjek merasa tertarik pada bidang atau hal tertentu dan merasa senang berkecimpung dalam bidang itu (Winkel 1983:30). Perasaan senang akan menimbulkan minat pula, yang diperkuat lagi oleh sikap yang positif, yang mana di antara hal-hal itu timbul lebih dahulu, sukar ditentukan secara pasti. Pada umumnya berlaku urutan psikologi sebagai berikut: perasaan senangsikap positif-minat.

Minat orang tua memasukkan anaknya ke lembaga pendidikan agama berfungsi memelihara kelurganya terutama anaknya semoga terhindar dari segala macam ancaman baik di dunia mapun diakhirat kelak. Setiap orang tua diperintahkan untuk memelihara keluarganya dari ancaman api neraka.

Minat masyarakat terhadap madrasah merupakan kecenderungan orang tua wali dalam memilih pendidikan untuk anaknya. Wujud dari implementasi minat adalah menyekolahkan anak mereka ke madrasah sebagai pilihan untuk pendidikan anak.

\section{METODE PENELITIAN}

Penelitian ini menggunakan Research and Development yaitu metode penelitian yang digunakan untuk menghasilkan produk tertentu, dan menguji keefektifan produk tersebut. ${ }^{7}$ Meskipun demikian,

${ }^{7}$ Sugiyono. 2010. Metode Penelitian Pendidikan, Pendekatan Kuantitatif, Kualitatif, dan RED. Bandung: Alfabeta, h. 407. dalam penelitian ini hanya sampai pada menghasilkan produk tertentu, yakni model peningkatan minat masyarakat untuk menyekolahkan anaknya di madrasah.

Penelitian dilakukan pada MI dan MTs yang ada di Kabupaten Magelang dan Kabupaten Demak Jawa Tengah. Locus penelitian ini ada pada MI Ma'arif Grabag 1 Magelang, MI Ma'arif Donorojo, MI Muhammadiyah Munkid, MI Terpadu Muhammadiyah Harapan Magelang, MTs Arrosyidin Secang, MTs Arrosyidin Madusari, MTs Muhammadiyah Munkid, dan MTs Sultan Fatah Demak. Penelitian ini difokuskan di dua kabupaten; Magelang dan Demak sebagai sentra-madrasah di Jawa Tengah.

Teknik pengumpulan data yang digunakan dalam penelitian ini adalah observasi, telaah dokumen, angket, wawancara, serta focus group discussion (FGD). Teknik Analisis yang dikembangkan mengikuti 5 (lima) dari 10 (sepuluh) tahapan yang dikembangkan Borg and Gall, yakni (1) research and information collecting, (2) planning, (3) develop primary form of product, (4) preeliminary field testing, dan (5) main product revision. Penelitian ini dilakukan mulai Januari sampai dengan Juni 2012.

\section{HASIL DAN PEMBAHASAN}

Pilihan terhadap kabupaten Demak dan kabupaten Magelang didasarkan pada data emis yang menyebutkan bahwa jumlah MI terbanyak ada di Kabupaten Magelang dan jumlah MTs terbanyak ada di kabupaten Demak. MI di kabupaten Magelang berjumlah 303 madrasah, sementara MTs di Kabupaten Demak berjumlah 119 madrasah.

\section{Minat Masyarakat terhadap Madrasah di Jawa Tengah}

Minat masyarakat memilih madrasah untuk memasukkan anak mereka pada MI dan MTs diperoleh melalui data sebagai 
berikut (1) memenuhi standar isi [89,75 \%], (2) standar proses [86,83\%], (3) standar kompetensi lulusan [93\%], (4) standar sarana dan prasarana $[77,85 \%],(5)$ standar pembiayaan $[80,09 \%]$, (6) standar penilaian pendidikan [92,33\%], (7) publikasi dan prestasi madrasah [90,4\%], dan (8) madrasah yang ideal sesuai kebutuhan masyarakat $[85,92 \%]$.

Program unggulan yang dipersepsi baik oleh orang tua/wali adalah pembiasaan sholat dhuhur berjama'ah, sholat dhuha, hafalan surat pendek, bahasa Inggris, bahasa Arab, dan jaringan internet. Adapun bentuk partisipasi masyarakat terhadap madrasah meliputi: sumbangan pikiran, sumbangan finansial, dan sumbangan tenaga. Dalam bentuk sumbangan pikiran misalnya duduk sebagai komite, selalu datang ketika diundang pihak madrasah, dan aktif memberikan saran-masukan untuk perbaikan madrasah. Dalam bentuk sumbangan finansial adalah membayar biaya pendidikan secara rutin dan on time, memberikan infak harian/bulanan/insidental baik berupa uang maupun material (pasir, batu bata, semen, dsb). Dalam bentuk sumbangan tenaga misalnya aktif dalam kegiatan kerja bakti membangun madrasah.

Harapan umum orang tua menyekolahkan di madrasah adalah agar diperoleh anak yang sholeh. Selain itu, diharapkan agar anaknya taat beribadah, berbakti kepada orang tua, dan bisa mendoakan ketika orang tua sudah meninggal dunia.

Secara umum, madrasah yang diminati masyarakat (siswanya banyak) adalah madrasah yang berada di pedesaan. Selain itu, faktor akreditasi A tidak menjadi jaminan bahwa madrasah tersebut diminati oleh masyarakat. Meskipun harus dipahami bahwa minat masyarakat yang tinggi terhadap madrasah dipengaruhi oleh bentuk layanan pendidikan yang diberikan oleh madrasah. Delapan (8) standar nasional pendidikan menjadi perhatian penting yaitu standar isi, standar proses, standar kompetensi lulusan, standar sarana dan prasarana, standar pembiayaan, dan standar penilaian pendidikan. Di antara yang terpenting adalah standar kompetensi lulusan (SKL).

Minat yang tinggi dari masyarakat untuk menyekolahkan anaknya pada madrasah tentu merupakan buah dari usaha serius yang dilakukan pihak madrasah. Meskipun demikian, terkadang faktor non ilmiah pun mempengaruhi minat masyarakat terhadap madrasah. Sebagai contoh beberapa orang tua/wali siswa MI Grabag 1 menyampaikan bahwa mereka menyekolahkan anak di situ karena kebetulan waktu pulang siswa-siswinya pukul 13.30 WIB ini cocok dengan waktu pulang kerja mereka, sehingga bisa antar jemput.

\section{Model Peningkatan Minat Masyarakat ter- hadap Madrasah}

Model adalah tipe, contoh, corak, macam, atau rancang bangun. Model diperoleh melalui penyederhanaan (simplification) terhadap sesuatu yang sebenarnya kompleks. Model berfungsi sebagai penyederhanaan realitas sehingga dapat digambarkan secara ringkas namun jelas. Model madrasah yang diminati adalah suatu tipe atau rancang bangun madrasah dimana jumlah peserta didik atau calon peserta didik yang melebihi kapasitas atau daya tampung suatu madrasah (banyak). Pihak madrasah selalu menyeleksi atau memilih calon siswa yang akan diterima. Dengan kata lain, pihak madrasah menolak banyak calon pendaftar karena alsan keterbatasan kuota.

Beberapa hal menjadi perhatian agar bisa mendongkrak minat masyarakat terhadap madrasah adalah sebagai berikut.

\section{Pembentukan Image Positif Madrasah}

Madrasah memegang dua peran sekaligus yakni peran pendidikan agama dan sekaligus pendidikan umum. Di sinilah sesungguhnya kelebihan sekaligus 
kelemahan madrasah. Jika dua peran ini bisa dimainkan secara baik justeru menjadi daya tarik madrasah, namun jika gagal madrasah mengidap persoalan utama. Kesan masyarakat yang positif terhadap madrasah diperoleh melalui ungkapan "ilmu agama dapat, ilmu umum juga dapat", usaha untuk menjadikan anak sholeh, dan sebagainya.

Citra negatif madrasah di antaranya adalah mutu pendidikan rendah, ilmu umum ketinggalan, ilmu agama tidak dapat (mogol), dan ungkapan-ungkapan sejenis lainnya. Madrasah yang baik harus bisa membuang kesan negatif yang ada di masyarakat melalui upaya nyata peningkatan prestasi. Pembentukan citra positif madrasah dilakukan dengan kesungguhan para pengelola madrasah (kepala madrasah, guru, yayasan/komite) untuk berkomitmen (junun/perhatian penuh/bukan samben) dalam memajukan madrasah. Sehingga kesan madrasah sebagai sekolah pinggiran, ketinggalan, kurang mutu, second-class, bisa dihapuskan.

Secara umum, kesan yang didapat adalah madrasah tertinggal mutu khususnya untuk pendidikan umum. Oleh karena itu, jika madrasah mampu meningkatkan prestasi di bidang umum, maka madrasah akan mendapatkan image yang positif. Dengan citra atau image yang positif, maka madrasah akan disenangi masyarakat. Dengan disenanginya madrasah oleh masyarakat, minat masyarakat terhadap madrasah juga akan meningkat. Secara teoretik minat masyarakat akan diperoleh melalui proses: image positif-disenangi-diminati.

\section{Peningkatan Prestasi Madrasah; Akademik dan Non Akademik}

Prestasi adalah kata kunci apapun aktivitas kita. Dalam dunia pendidikan prestasi tentu menyangkut tiga hal; prestasi madrasah, prestasi guru, dan prestasi siswa. Madrasah yang diminati adalah madrasah yang berprestasi di berbagai bidang.
Demikian juga, gurunya harus berprestasi serta memiliki komitmen yang tinggi untuk memajukan madrasah. Namun, untuk kepentingan menarik minat masyarakat terhadap madrasah yakni dengan peningkatan prestasi siswa. Prestasi siswa yang paling mudah dilihat oleh masyarakat adalah hasil ujian nasional (UN).

Oleh karena itu, pencapaian UN adalah mutlak agar madrasah tidak dilihat sebelah mata oleh masyarakat. Pencapaian UN merupakan suatu keharusan. Lebih penting juga adalah publikasi madrasah terhadap prestasi UN yang telah diraih madrasah tersebut. Selain prestasi UN, penting juga adalah prestasi Ujian Akhir Madrasah Bertaraf Nasional (UAMBN).

Beberapa UPTD Dinas Pendidikan, ketika madrasah yang mendapat ranking prestasi UN biasanya tidak publikasikan. Tetapi jika pihak sekolah yang mendapatkan ranking prestasi UN, selain dipublikasikan juga mendapatkan piala bergilir. Bentuk 'pendzoliman' dinas pendidikan terhadap madrasah hemat kami tidak perlu disikapi negatif. Pihak madrasah bisa membuat publikasi sendiri tentang prestasi UN tersebut. Selain prestasi akademik, tidak kalah penting juga adalah prestasi siswa di bidang non akademik. Banyak kegiatan lomba-lomba yang harus diikuti oleh pihak madrasah agar eksistensinya diakui. Apapun lombanya, idealnya pihak madrasah selalu mengikutkan siswa-siswinya. Tidak boleh ada pikiran, pihak madrasah rugi jika mengikutkan perlombaaan untuk anak didiknya. Apalagi kalau hanya alasan takut kalah.

Selain melalui out put, prestasi madrasah juga diukur melalui out come madrasah. Pencapaian prestasi siswa UN/UAMBN/ lomba-lomba, penting untuk diraih siswa, tetapi outcome siswa dalam arti banyak yang diterima di pendidikan favourit (madrasah, sekolah, ataupun pesantren) juga tidak kalah penting. Ini adalah bentuk publikasi yang mudah dilihat oleh masyarakat. Yak- 
ni lulusan madrasah diterima di berbagai lembaga yang bonafid.

\section{Intensifikasi dan Ekstensifikasi Publikasi Madrasah}

Publikasi madrasah berfungsi layaknya marketing madrasah. Pengelola madrasah perlu terus mempublikasikan madrasah melalui berbagai media: spanduk, mading, brosur, baliho, pamflet, kalender, surat kabar, radio, jejaring sosial (fb, twitter) dan lain sebagainya. Kegiatan publikasi madrasah juga bisa dilakukan dengan mengadakan kegiatan yang melibatkan masyarakat secara langsung dalam berbagai bentuk: jalan sehat, penyembelihan hewan qurban, bersih-bersih masjid, makam, keikutsertaan dalam pengurusan jenazah masyarakat.

Publikasi madrasah setidaknya menyangkut dua content; prestasi madrasah dan penerimaan siswa baru. Apapun prestasi madrasah, baik akademik maupun non akademik, yang diraih madrasah hendaknya dipublikasikan secara intens oleh pihak madrasah. Prestasi madrasah sekecil apapun hendaknya dipublikasikan dengan baik.

Publikasi madrasah juga menyangkut penerimaan siswa baru. Pihak madrasah perlu melakukan strategi penerimaan siswa baru yang efektif dengan berbagai cara. Bisa juga mempertimbangkan penerimaan siswa baru yang lebih awal dan lebih lama. Pihak madrasah harus melakukan sosialisasi intensif ke TK/RA/BA (jika MI) atau MI/SD (jika MTs). Selain itu, pendekatan silaturahim kepada tokoh masyarakat dan tokoh agama di mana madrasah itu berada sangat penting dilakukan.

Promosi madrasah dilakukan dengan berbagai cara; antara lain: melibatkan masyarakat dalam kegiatan madrasah atau sebaliknya melibatkan siswa dalam kegiatan masyarakat. Pelibatan masyarakat dalam kegiatan madrasah tidak hanya pada saat madrasah membutuhkan biaya tetapi termasuk dalam berbagai hal kaitannya dengan pendidikan. Bentuk tahajjud call, komunikasi intensif guru-wali murid, perhatian spesifik pada setiap siswa; berprestasi ataupun bermasalah, dan lain sebagainya.

\section{Program Unggulan yang Berorientasi Ke- butuhan Masyarakat}

Program unggulan madrasah yang berorientasi kebutuhan masyarakat sejatinya menempatkan anak sebagai subjek dan tujuan keberhasilan semua pihak di madrasah. Siswa ditempatkan sebagai pemangku kepentingan utama harus merasa bernilai belajar di madrasah. Secara mudah adalah terbentuknya anak sholeh/sholehah dan berakhlakul karimah. Oleh karena itu, program unggulan bertujuan untuk penciptaan budaya Islami di madrasah.

Persoalan akhlak dalam pendidikan madrasah merupakan sesuatu yang sentral. Bahkan, kehadiran Nabi Muhammad ke muka bumi pada hakikatnya adalah untuk memperbaiki akhlak manusia. Sehingga, persoalan akhlak menjadi sentral dalam kegiatan di madrasah. Tidak hanya terhadap siswa, termasuk juga pihak kepala dan guru yang memberikan teladan akhlak yang baik bagi masyarakat di lingkungan sekitar.

Bahkan, beberapa MI justru menjadikan persoalan akhlak ini lebih penting daripada prestasi UN. Pembiasan-pembiasaan di madrasah kaitannya dengan pembentukan akhlak menjadi sangat sentral agar madrasah diminati masyarakat; berjabat tangan dengan guru, mengingatkan sholat malam (tahajud call), dan pelibatan siswa untuk membantu kegiatan di masyarakat.

Aktivitas siswa madrasah baik untuk kegiatan ibadah (sholat berjamaah) maupun kegiatan sosial ada baiknya membaur dengan masyarakat sekitar. Dengan demikian, akan terjalin komunikasi intensif antara pihak madrasah dengan masyarakat. 
Beberapa program unggulan yang muncul dalam penelitian bisa dibagi menjadi progam unggulan bidang agama dan program unggulan bidang umum. Program unggulan di bidang agama misalnya: 1) Baca Tulis Al-Qur'an, 2) Tahzfidzul Qur'an, 3) Tilawah, 4) Pembiasaan sholat berjamaah terutama Dzhuhur dan Dhuha, 5) Penguasaan bahasa asing (Arab dan Inggris), 6) Hafalan surat-surat pendek (Juz Amma), 7) Cerdas cermat agama, dan 8) Pidato Bahasa Arab/Inggris. Program unggulan di Bidang umum meliputi: 1) Perlombaan olah raga (sepak bola, badminton dsb), 2) Seni tari dan seni musik (rebana), 3) Pramuka, 4) Drum band dan 5) Teknologi informasi/ Jaringan Internet.

\section{Pemenuhan Standar Nasional Pendidikan}

Pemenuhan Standar Nasional Pendidikan (SNP) meliputi: (1) stadar isi, (2) standar proses, (3) standar kompetensi lulusan, (4) standar pendidik dan tenaga kependidikan, (5) standar sarana dan prasarana, (6) standar pengelolaan, (7) standar pembiayaan, dan (8) standar penilaian.

Dari delapan (8) standar nasional pendidikan tersebut, berdasarkan persepsi masyarakat dan pengelola madrasah yang diunggulkan adalah standar kompetensi lulusan. Artinya, stakeholder madrasah meyakini bahwa standar kompetensi lulusan dalam arti out put siswa menjadi sentral dalam peningkatan minat masyarakat terhadap madrasah. Hal ini mengingat, masih adanya kesan umum bahwa madrasah sebagai sekolah pinggiran, kurang mutu, dan terbelakang dibandingkan dengan sekolah.

Dari delapan (8) standar nasional pendidikan tersebut, berdasarkan persepsi masyarakat dan pengelola madrasah yang dipersepsi rendah adalah standar sarana dan prasarana. Hal ini, wajar karena sebagian besar madrasah adalah swasta sehingga sarana dan prasarananya masih kurang dibandingkan yang madrasah negeri.
Pemenuhan SNP menjadi kewajiban seluruh madrasah untuk meningkatkan layanan pendidikan. Meskipun, berdasarkan hasil penelitian pemenuhan standar nasional pendidkan bukan merupakan faktor penentu utama masyarakat menyekolahkan anaknya ke madrasah. Dalam hal ini adalah akreditasi madrasah. Artinya, madrasah yang terakreditasi A tidak otomatis lebih diminati daripada madrasah dengan status akreditasi B dan seterusnya. Namun, dalam pelaksanaan pendidikan, otomatis bahwa akreditasi menentukan kualitas pendidikan yang ada di suatu satuan pendidikan.

\section{Packaging Madrasah yang Menarik}

Secara isi madrasah sudah menarik, namun jika tidak dikemas dengan menarik bisa jadi madrasah tidak akan diminati. Mafhum bahwa antara SDIT dengan MI tidak ada perbedaan sama sekali. Namun, peminat orang tua menyekolahkan anaknya ke SDIT secara umum tinggi, tetapi tidak sebaliknya untuk MI. Secara isi MI dan SDIT sama persis, mapel agama yang diajarkan juga sama (Al-Qur'an Hadits, Fiqh, Aqidah Akhlak, SKI). Perbedaanya hanya satu yakni soal kemasan. Banyak madasah tidak pandai mengemasnya sehingga menarik. (Hasil Penelitian Puslitbang Pendidikan Agama dan Keagamaan, 2009, Fenomena Madrasah Bubar dan Islamic Full Day School).

Terlepas dari upaya di atas, keteladanan ada hal utama untuk peningkatan minat masyarakat terhadap madrasah. Secara praktis, kepala madrasah, para guru madrasah, para pegawai Kementerian Agama, hendaknya menyekolahkan anak mereka ke madrasah. Jika keluarga besar madrasah sendiri tidak percaya terhadap madrasah, bagaimana akan meyakinkan orang lain untuk menyekolahkan anak mereka ke madrasah? Dengan cara ini, masyarakat akan berbondong-bondong untuk mempercayakan anaknya ke madrasah. 
Enam (6) strategi peningkatan masyarakat terhadap madrasah seperti yang diuraikan di atas merupakan strategi umum. Apa dan bagaimanapun kondisi madrasahnya, 6 cara tersebut harus dilakukan dalam kerangka peningkatan minat masyarakat terhadap madrasah. Dalam bentuk bagan, upaya peningkatan minat masyarakat terhadap madrasah adalah sebagai berikut.

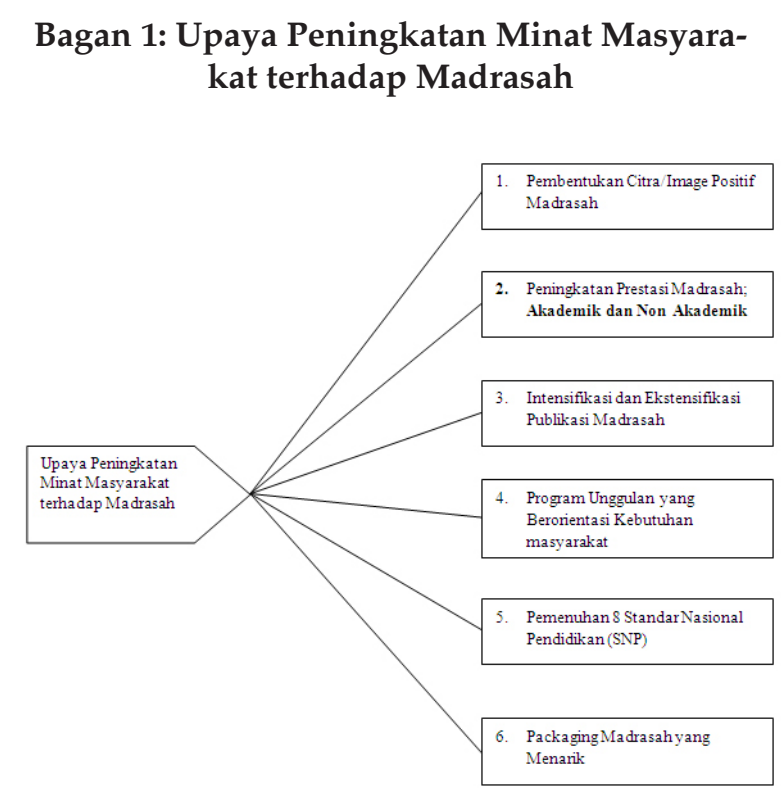

Peningkatan minat masyarakat terhadap madrasah dipengaruhi dua faktor utama yakni: karakteristik madrasah dan karakteristik masyarakat pengguna madrasah tersebut. Artinya, sesungguhnya di dalam peningkatan minat masyarakat tersebut perlu juga mempertimbangkan strategi khusus terkait dengan karakteristik madrasah maupun masyarakat yang berbeda. Namun demikian, kata kuncinya adalah peningkatan minat masyarakat terhadap madrasah akan terjadi manakala madrasah tersebut mampu memenuhi kebutuhan masyarakat para pengguna madrasah itu.

Berikut ini adalah karakteristik madrasah yang perlu diperhatikan dalam upaya peningkatan minat masyarakat terhadap madrasah.
Bagan 2: Karakteristik Madrasah

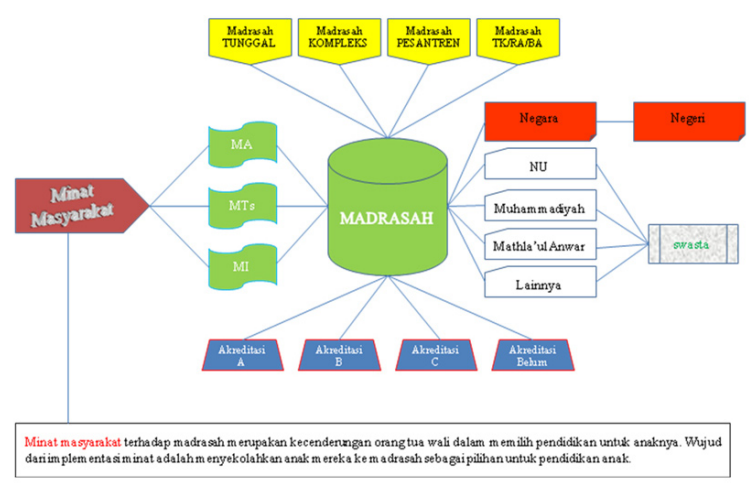

Berbicara mengenai peningkatan minat masyarakat terhadap madrasah perlu mempertimbangkan empat hal kaitannya dengan realitas di lapangan tentang kondisi madrasah tersebut: jenjang madrasah, akreditasi madrasah, eksistensi madrasah, dan pengelola madrasah.

\section{Jenjang Madrasah}

Strategi peningkatan minat masyarakat terhadap madrasah antara MI-MTsMA tentu tidak sama. Secara kasat mata, MI yang diminati adalah yang memiliki jenjang dibawahnya TK/RA/BA. Tetapi tidak harus bahwa MTs yang diminati adalah MTs yang memiliki MI. Demikian juga, program-program unggulan harus juga disesuaikan dengan jenjang madrasah tersebut.

\section{Akreditasi Madrasah}

Akreditasi madrasah secara formal menggambarkan kualitas madrasah. Akreditasi madrasah terdiri atas $\mathrm{A}, \mathrm{B}, \mathrm{C}$ dan belum terakreditasi. Hendaknya setiap madrasah selalu memperhatikan akreditasinya sebagai ukuran formal peningkatan kualitas satuan pendidikan.

Secara umum, madrasah yang memiliki akreditasi yang baik (A/B) akan diminati masyarakat daripada madrasah yang berakreditasi $C$ ataupun belum terakreditasi. Tetapi tidak berarti bahwa madrasah 
yang terakreditasi A selalu lebih diminati daripada madrasah yang terakreditasi B.

\section{Eksistensi Madrasah}

Dilihat dari eksistensi madrasah paling tidak dikenal 4 (empat) varian model madrasah yaitu: (1) Madrasah Tunggal/Biasa, (2) Madrasah Satu Kompleks, (3) Madrasah Pesantren, dan (4) Madrasah Plus RA/TK.

Madrasah tunggal adalah madrasah yang berdiri mandiri hanya satu jenis saja. Misal MI saja atau MTs saja, ataupun MA saja. Contoh di Demak adalah MI Sultan Fatah. Sementara di Magelang misalnya MTs Muhammadiyah Bumirejo Munkid. Madrasah kompleks adalah madrasah yang terdiri atas gabungan beberapa madrasah: MI dan MTs atau MTs dan MA, ataupun MI, MTs, dan MA sekaligus. Contoh di Magelang adalah MI dan MTs Arrosyidin Madusari Secang. Madrasah pesantren adalah madrasah yang berada di lingkungan pesantren. Misalnya MTs dan MA Yajri Payaman, MTs dan MA Pabelan. Madrasah plus TK/RA/BA adalah madrasah Ibtidaiyah yang dilengkapi dengan Taman Kanakkanak atau Raudlatul Athfal atau Bustanul Athfal. Misalnya MI Ma'arif Donorojo memiliki RA. MI Muhammadiyah Munkid memiliki Bustanul Athfal. MI Ma'arif Madusari memiliki TK Masyitoh. Perbedaan eksistensi madrasah menyebabkan adanya perbedaan strategi peningkatan minat masyarakat terhadap madrasah.

\section{Pengelolaan Madrasah}

Madrasah bisa dilihat dari siapa penyelenggaranya. Secara umum, penyelenggara madrasah ada dua yakni pemerintah (madrasah negeri) dan masyarakat (madrasah swasta). Madrasah swasta paling tidak diselenggarakan oleh beberapa organisasi masyarakat seperti Nahdlatul Ulama (NU), Muhammadiyah, Mathlaul Anwar, ataupun yayasan lokal yang tidak secara eksplisit berafiliasi kepada ormas tertentu.
Beberapa nama yayasan misalnya Arrosyidin, Al-Ittihad, Al-Iman, dan sebagianya.

Adanya varian-varian yang berbeda tentu akan mempengaruhi treatment bagaimana meningkatkan minat masyarakat terhadap madrasah yang tidak sama antara satu madrasah dengan madrasah lainnya. Apalagi kenyataan beragam ideologi yang berbeda antara madrasah satu dengan lainnya; Tradisionalis, Reformis, Salafi, dan Nasima. Minat masyarakat terhadap madrasah tergolong tinggi terutama pada madrasah yang berada di daerah pinggiran dan atau pedesaan.

\section{PENUTUP}

\section{Kesimpulan}

1. Minat masyarakat memilih madrasah untuk memasukkan anak mereka pada MI dan MTs di Kabupaten Magelang dan Demak adalah sebagai berikut (1) memenuhi standar isi [89,75\%], (2) standar proses [86,83\%], (3) standar kompetensi lulusan [93\%], (4) standar sarana dan prasarana [77,85\%], (5) standar pembiayaan [80,09\%], (6) standar penilaian pendidikan [92,33\%], (7) publikasi dan prestasi madrasah [90,4 $\%$ ], dan (8) madrasah yang ideal sesuai kebutuhan masyarakat [85,92 \%], (9) hal-hal yang mendorong menyekolahkan ke madrasah, (10) program-program unggulan, (11) bentuk partisipasi, serta adanya (12) harapan orang tua menyekolahkan di madrasah.

2. Beberapa hal yang bisa meningkatkan jumlah peserta didik madrasah yakni madrasah yang memperhatikan aspek penilaian masyarakat dan pengelolaan madrasah melalui (1) Pembentukan citra positif madrasah di masyarakat, (2) peningkatan prestasi madrasah; akademik dan non akademik, (3) Intesifikasi dan Ekstensifikasi Publikasi madrasah, (4) Program unggulan yang berorientasi kebutuhan masyarakat, dan (5) Pe- 
menuhan Standar Nasional Pendidikan (SNP), serta (6) Packaging madrasah yang menarik.

\section{Saran}

1. Madrasah perlu melakukan usaha-usaha kongkrit dalam upaya peningkatan jumlah peserta didiknya melalui berbagai langkah seperti penyusunan program unggulan, jalinan komunikasi intensif dengan orang tua/wali, publikasi madrasah, dan peningkatan prestasi madrasah.

2. Pihak madrasah perlu memperhatikan aspek penilaian masyarakat terhadap madrasah yang bersangkutan melalui berbagai bentuk penyelenggaraan kegiatan. Kegiatan tersebut hendaknya melibatkan masyarakat untuk berpartisipasi, ataupun sebaliknya pihak madrasah yang turut berpartisipasi dalam kegiatan masyarakat.

3. Secara praktis madrasah perlu melakukan: (1) pembentukan citra positif madrasah di masyarakat, (2) peningkatan prestasi madrasah; akademik dan non akademik, (3) intesifikasi dan ekstensifikasi publikasi madrasah, (4) Program unggulan yang berorientasi kebutuhan masyarakat, dan (5) pemenuhan Standar Nasional Pendidika, dan (6) Packaging madrasah yang menarik.

\section{SUMBER BACAAN}

Aly, Abdullah (2011): Pendidikan Islam Multikultural di Pesantren; Telaah terhadap Kurikulum Pondok Pesantren Modern Islam Assalam Surakarta. Yogyakarta: Pustaka Pelajar.

Achmad, Zainal (2007): Analisis Tingkat Partisipasi Pendidikan Siswa Madrasah. www.kemenag.go.id.

Gall, Meredith D. Joyce P Gall dan Walter R Borg (2003): Educational Research an Interoduction $\left(7^{\text {th }} \mathrm{ed}\right.$ ). New York: Pearson Education Inc.
Peraturan Pemerintah RI Nomor 19 Tahun 2005 tentang Standar Nasional Pendidikan.

Saridjo, Marwan (1996): Bunga Rampai Pendidikan Agama Islam. Jakarta: CV Amissco.

Slameto (1995): Belajar dan Faktor-faktor yang Mempengaruhi. Jakarta: Rineka Cipta.

Sugiyono (2010): Metode Penelitian Pendidikan, Pendekatan Kuantitatif, Kualitatif, dan RED. Bandung: CV Alfabeta.

Suprayogo, Imam (2007): Quo Vadis Madrasah; Gagasan, Aksi, dan Pembangunan Madrasah. Jakarta: Puslitbang Pendidikan Agama dan Keagamaan.

Syah, Muhibbin (2004): Psikologi Pendidikan dengan Pendekatan Baru. Bandung: PT Remaja Rosdakarya.

Syukur, Fatah (2011): Manajemen Pendidikan Berbasis pada Pesantren. Semarang: PT Pustaka Rizki Putra.

Taruna, Mulyani Mudis (2009) Pelaksanaan KTSP pada Madrasah Tsanawiyah Negeri di Kalimantan Selatan, Jawa Timur, dan DIY. Semarang: Balai Litbang Agama Semarang.

Undang-undang RI Nomor 20 Tahun 2003 Tentang Sistem Pendidikan Nasional.

Winkel, WS (1983): Psikologi Pendidikan dan Evaluasi Belajar. Jakarta: PT Gramedia.

Yusuf, Choirul Fuad, dkk (2006): Revitalisasi Madrasah. Puslitbang Pendidikan Agama dan Keagamaan Jakarta.

-, Potret Madrasah di Media Massa. Puslitbang Pendidikan Agama dan Keagamaan Jakarta.

---------, Isu-isu Sekitar Madrasah. Puslitbang Pendidikan Agama dan Keagamaan Jakarta.

Inovasi Pendidikan Agama. Puslitbang Pendidikan Agama dan Keagamaan Jakarta. 